\title{
Technoeconomic Assessment on Innovative Biofuel Technologies: The Case of Microalgae
}

\author{
Lauro André Ribeiro ${ }^{1}$ and Patrícia Pereira da Silva ${ }^{2}$ \\ ${ }^{1}$ School of Sciences and Technology, University of Coimbra and INESCC, R. Antero de Quental, 199 3000-033 Coimbra, Portugal \\ ${ }^{2}$ School of Economics, University of Coimbra and INESCC, Avenue Dias da Silva, 165 Room 207, 3004-512 Coimbra, Portugal \\ Correspondence should be addressed to Lauro André Ribeiro, lribeiro@inescc.pt
}

Received 2 April 2012; Accepted 28 May 2012

Academic Editors: E. R. Bandala, B. Chen, and K. T. Lee

Copyright (C) 2012 L. A. Ribeiro and P. Pereira da Silva. This is an open access article distributed under the Creative Commons Attribution License, which permits unrestricted use, distribution, and reproduction in any medium, provided the original work is properly cited.

\begin{abstract}
Innovative technologies and sources of energy must be developed to replace fossil fuels and contribute to the reductions of emissions of greenhouse gases associated with their use. In this perspective, algal biofuels are generating substantial awareness in many countries. As of today, it has been shown that it is scientifically and technically possible to derive the desired energy products from algae in the laboratory. The question lies, however, in whether it is a technology that merits the support and development to overcome existing scalability challenges and make it economically feasible. In this context, the overall purpose of this study is to provide an integrated assessment of the potential of microalgae as a source to produce biofuels, while confronting it with competing emerging biofuel technologies. It is intended to provide a comprehensive state of technology summary for producing fuels from algal feedstocks and to draw some insights upon the feasibility and technoeconomic challenges associated with scaling up of processes.
\end{abstract}

\section{Introduction}

Innovative technologies and sources of energy must be developed to replace fossil fuels and contribute to the reductions of emissions of greenhouse gases associated with their use. Biofuels are particularly important as an option for means of transportation that lack other fuel options (especially trucks, ships, and aircrafts). However, alternative sources of biofuel derived from terrestrial crops such as sugarcane, soybeans, maize, rapeseed, among others impose pressure on food markets, contribute to water scarcity, and precipitate forest devastation. In this way, the sustainability of biofuels will depend on the development of viable, sustainable, advanced technologies that do not appear to be yet commercially viable.

In this perspective, algal biofuels are generating substantial awareness in many countries. In the United States, they may contribute to achieve the biofuel production targets set by the Energy Independence and Security Act of 2007. Likewise, in the European Union, they may assist to the achievement of goals established in the recent Renewables Directive. In order to address the technical-economic barriers to the further development of this type of bioenergy, it is thus necessary to contribute with a study that incorporates biomass feedstock availability assessment, production, management, and harvesting in support of the upscaling of this promising technology.

Different bioenergy pathways are at various stages of maturity. Several technologies' most critical need is to demonstrate efficiency at the appropriate scale-pilot plants, precommercial demonstration or full industrial scale. By 2020, the contribution to the EU energy mix from costcompetitive bio-energy used in accordance with the sustainability criteria of the new RES directive could be at least 14\% [1].

In this context, the overall purpose of this study is to provide an integrated assessment of the potential of microalgae as a source to produce biofuels, while confronting it with competing emerging biofuel technologies. It is intended to provide a comprehensive state of technology summary 
for producing fuels from algal feedstocks and to draw some insights upon the feasibility and technoeconomic challenges associated with scaling up of processes.

1.1. A Synopsis for Microalgae. Several studies have been conducted on the technical feasibility of growing algae for biofuel production in the laboratory [3,5-15], which have proved absence of the major drawbacks associated with current biofuels. However, the costs of producing this new fuel are still too high compared with other biofuel sources.

This technology uses the oils from microalgae as the raw material to produce biofuel. Microalgae are microscopic photosynthetic organisms that are found in both marine and freshwater. These organisms use solar energy to combine water with carbon dioxide $\left(\mathrm{CO}_{2}\right)$ to create biomass [12]

The mechanism of photosynthesis in microalgae is similar to higher plants, with the difference that the conversion of solar energy is generally more efficient because of their simplified cellular structure and more efficient access to water, $\mathrm{CO}_{2}$, and other nutrients. For these reasons, microalgae are capable of producing 30 times as much oil per unit of land area compared to terrestrial oilseed [12].

Algae can be autotrophic or heterotrophic; the first require only inorganic compounds such as $\mathrm{CO}_{2}$, salts, and a source of light energy for their growth, while the latter are nonphotosynthetic, therefore requiring an external source of organic compounds and nutrients as a source of energy [6].

In microalgae cultivation, carbon dioxide must be fed constantly during daylight hours. Algae biodiesel production can potentially use some of the carbon dioxide that is released in power plants by burning fossil fuels. This $\mathrm{CO}_{2}$ is often available at little or no cost [3]. However, the fixation of the waste $\mathrm{CO}_{2}$ of other sorts of business could represent another source of income to the algae industry. This sort of fixation is already being made in some large algae companies in a trail basis; though, there is a lack of public data of the results yet. Although this is a very promising future possibility, and some species have proven to show themselves capable of using the flue gas as nutrients, there are few species that survive at high concentrations of $\mathrm{NO}_{x}$ and $\mathrm{SO}_{x}$ present in these gases [16].

Ideally, microalgal biodiesel would be carbon neutral, as all the power needed for producing and processing the algae would come from biodiesel itself and from methane produced by anaerobic digestion of biomass residue left behind after the oils have been extracted. Although microalgal biodiesel can be carbon neutral, it will not result in any net reduction in carbon dioxide that is accumulating as a consequence of burning of fossil fuels [3].

The nutrients for the cultivation of microalgae (mainly nitrogen and phosphorus) can be obtained from liquid effluent wastewater (sewer); therefore, besides providing its growth environment, there is the potential possibility of waste effluents treatment [17]. This could be explored by microalgae farms as a source of income in a way that they could provide the treatment of public wastewater and obtain the nutrients the algae need.

After the process of extracting the oil from algae, the resulting product can be converted to biodiesel. The biodiesel produced from algal oil has physical and chemical properties similar to diesel from petroleum, to biodiesel produced from crops of 1st generation and compares favourably with the International Biodiesel Standard for Vehicles (EN14214) [6].

Like a refinery, it is still possible to obtain other products in the cultivation of microalgae, such as ethanol, methane, and biohydrogen. Although they are possible processes and proven in the laboratory, they were still little studied in industrial scale.

As of today, it has been shown that it is scientifically and technically possible to derive the desired energy products from algae in the laboratory. The question lies, however, in whether it is a technology that merits the support and development to overcome existing scalability challenges and make it economically feasible [18]. Economic viability is believed to be currently the main hurdle to overcome for this technology. Current costs associated to both the state of the science and technologies are sizeable and represent a main factor working against development.

Commercial algae production facilities employ both open and closed cultivation systems. Each of these has advantages and disadvantages, but both require high capital input. Closed photobioreactors are significantly more expensive to construct, but have not been engineered to the extent of other reactors in commercial practice, and so there may be opportunities for significant cost reductions. Neither open ponds nor closed photobioreactors are mature technologies. Therefore, until large-scale systems are built and operated over a number of years, many uncertainties will remain. Cultivation issues for both open and closed systems, such as reactor construction materials, mixing, optimal cultivation scale, heating/cooling, evaporation, $\mathrm{O}_{2}$ buildup, and $\mathrm{CO}_{2}$ administration, have been considered and explored to some degree, but more definitive answers await detailed and expansive scale-up evaluations [19].

\section{Comparing Feedstocks for Biofuel}

Biofuel production could be made from several sources. Among crops, it could be obtained from corn, sugar cane, switch grass, soybeans, rapeseed, canola, and so forth. Each crop has its own impacts and land-use requirements as stated in Table 1.

When the oil yield of different biofuel crops is compared, it becomes clearer that microalgae biofuels are far more efficient, as demonstrated in Table 2.

2.1. Algae-Based Biofuels Compensations. Contrasting to other sources of feedstock to produce biofuels, algaebased biofuels present several advantages. These advantages comprise

(1) capability of producing oil during all year long, therefore the oil productivity of microalgae is greater compared to the most efficient crops;

(2) producing in blackish water and on not arable land [20]; not affecting food supply or the use of soil for other purposes [3]; 


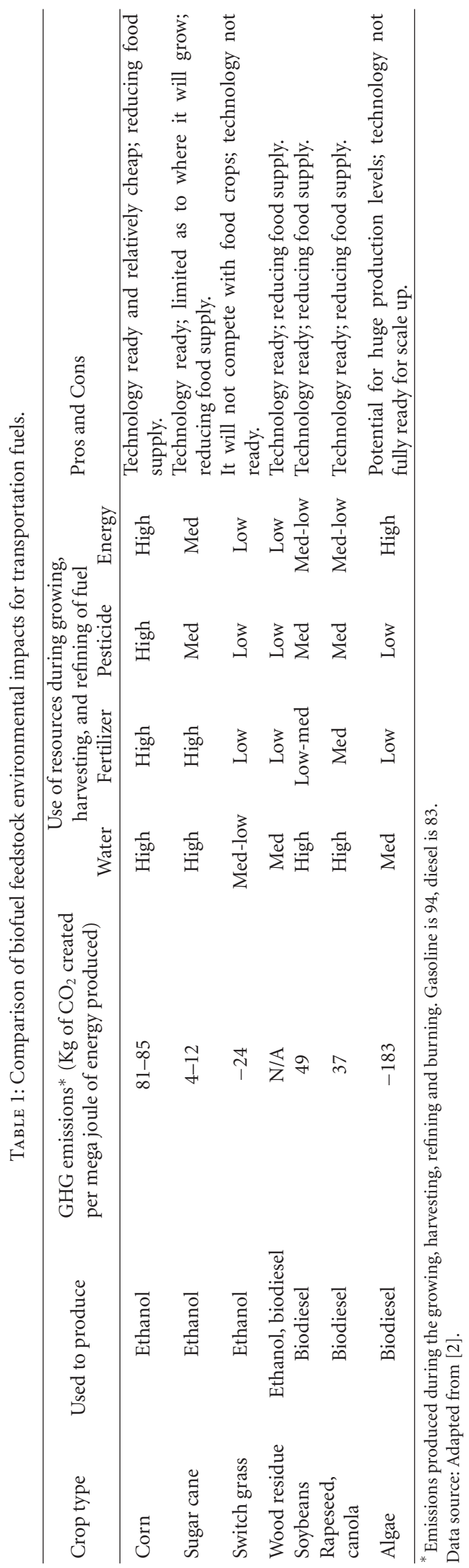


TABle 2: Comparison of estimated production and land-use requirement from various biofuel crops.

\begin{tabular}{lcc}
\hline Crop & Oil yield (L/ha) & Land area needed $(\mathrm{M} \mathrm{ha})^{\mathrm{a}}$ \\
\hline Corn & 172 & 1540 \\
Soybean & 446 & 594 \\
Canola & 1190 & 223 \\
Jatropha & 1892 & 140 \\
Coconut & 2689 & 99 \\
Palm oil & 5950 & 45 \\
\hline Microalgae $^{\mathrm{b}}$ & 136.900 & 2 \\
Microalgae $^{\mathrm{c}}$ & 58.700 & 4.5 \\
\hline
\end{tabular}

${ }^{a}$ For meeting $50 \%$ of all transport fuel needs of the United States.

b $70 \%$ oil (by weight) in biomass.

c30\% oil (by weight) in biomass.

Data source: [3].

(3) possessing a fast growing potential and several species has 20 to $50 \%$ of oil content by weight of dry biomass [3];

(4) regarding air quality, production of microalgae biomass can fix carbon dioxide ( $1 \mathrm{~kg}$ of algal biomass fixes roughly $1,83 \mathrm{~kg}$ of $\mathrm{CO}_{2}$ ) [3];

(5) nutrients for its cultivation (nitrogen and phosphorous, mainly) can be obtained from sewage; therefore, there is a possibility to assist the municipal wastewater treatment [17];

(6) growing algae do not require the use of herbicides or pesticides [21];

(7) algae can also produce valuable coproducts, as proteins and biomass after oil extraction, that can be used as animal feed, medicines, or fertilizers $[6,13]$, or fermented to produce ethanol or methane [8];

(8) biochemical composition of algal biomass can be modulated by different growth conditions, so the oil yield can be significantly improved [22]; and

(9) capability of performing the photobiological production of "biohydrogen" [23].

The above combination of the potential for biofuel production, $\mathrm{CO}_{2}$ fixation, wastewater treatment, and the possibility of production of biohydrogen highlights the potential applications of the microalgae cultivation.

Compared to other biofuel technologies, the most favourable factors for the cultivation of microalgae for the production of biofuels that they can be grown in brackish (salt) water, on nonfertile land and the oil yield production is far superior.

2.2. Claims against Algae-Based Biofuels. Despite its vocation as a potential source of biofuels, many challenges have hindered the development of biofuels technology from microalgae to become commercially viable. Among them, and based on recent literature, we elect as the most important:
(1) the selection of species must balance the requirements for biofuel production and extraction of valuable byproducts [9];

(2) achieve greater photosynthetic efficiency through the continuous development of production systems [24];

(3) developing techniques for growing a single species, reducing evaporation losses and diffusion of $\mathrm{CO}_{2}$ [15];

(4) few commercial cultivating "farms," so there is a lack of data on large-scale cultivation [10];

(5) impossibility of introducing flue gas at high concentrations, due to the presence of toxic compounds such as $\mathrm{NO}_{x}$ and $\mathrm{SO}_{x}[16]$;

(6) choosing algae strains that require fresh water to grow can be unsustainable for operations on a large scale and exacerbate fresh water scarcity [18];

(7) current harvest and dewatering are still too energy intensive [25];

(8) some recent life cycle analyses (LCAs) project algae biofuels as having poor energy or greenhouse gas benefits [26];

(9) another disappointment that will likely arise is the scarcity of sites with favorable climate, land, water, and $\mathrm{CO}_{2}$ resources, all required in one place [26];

(10) $\mathrm{CO}_{2}$ supply is relatively expensive, due to high capital and operational costs for piping $\mathrm{CO}_{2}$ to, and transferring it into, the ponds [26].

\section{Expectations towards Algae-Based Biofuels}

Although several challenges remain in the trail towards algae biofuels commercialisation and its adoption as a biofuel, as seen so far, an increasing number of companies and policy makers seem to believe the rewards outweigh the risks. Thus, the expectation pathway for algae-based biofuels remains uncertain.

Theoretically, microalgae have been shown to be a potential source to produce biodiesel because of their many advantages as a sustainable feedstock for biodiesel production compared to other feedstocks [27]. Nevertheless, not only more innovations are still needed for the development of technologies that reduce costs while increasing the yields of production [28], but also it is required a comprehensive set of policies to assist the development of microalgae technology.

In the management area, it is extremely important in the early phases of this promising industry to deliberate new business models that look at the bioenergy potential of algae through the transportation fuels market, as well as production of other higher value products so as to make the economics practicable [28].

3.1. Selected Algae Biofuel Economics. The current economic situation points towards large-scale production of algae biodiesel which has not yet been viable as a solution to 
TABLE 3: Recent investments from venture capital firms in algae firms.

\begin{tabular}{ll}
\hline Venture capital firms & Algae firms \\
\hline Aardvark Investments SA & Cequesta Algae \\
Arch Venture Partners & Sapphire Energy \\
BIRD Foundation & Algatech, GreenFuel \\
BlueCrest & Blue Marble Energy, \\
& Solazyme, Earth2tech \\
Braemar Energy Ventures & Solazyme \\
Cascade Ventures & Sapphire Energy, Cedar \\
& Grove Investments \\
Draper Fisher Jurvetson (DFJ) & GreenFuel Technologies \\
Gabriel Venture Partners & Corporation \\
Harris \& Harris Group & Aurora Biofuels \\
I2BF & Solazyme \\
Lightspeed Energy Partners & Solix Biofuels \\
Noventi (formerly Cypress Ventures) & Solazyme \\
Oak Investment Partners & Aurora Biofuels \\
Quercus Trust & Aurora Biofuels \\
Southern Ute Alternative Energy LLC & Livefuels \\
The Roda Group & Solix Biofuels \\
VantagePoint Venture Partners & Solazyme \\
Venrock & Solazyme \\
Wellcome Trust & Sapphire Energy \\
XL TechGroup, Australia & Sapphire Energy \\
\hline
\end{tabular}

Source: [4].

displace petroleum-based fuels. The technology to efficiently produce biodiesel which from microalgae is not up till now competitive with more advanced and emerging renewable technologies such as wind, solar, geothermal, and other forms of biomass. However, with policy support and incentives, the algal biofuel industry will continue to develop, and assuming that this technology follows renewable energy cost trends, costs will decrease to eventual economic viability. By assessing the viability of algae projects from a true market perspective, it is clearly apparent that total installed costs and operation and maintenance costs will be a major hurdle to future commercialization. Technologies must be developed to reduce costs and increase yields. This can be accomplished only through a focused, comprehensive, and well-funded $\mathrm{R} \& \mathrm{D}$ program. The rate of development of the technology is currently very fast, encouraging viability [18].

In this manner, many venture capital firms had made recent investments in algae fuel ventures. Some of the venture capital firms and the algae fuel companies they have invested in are outlined in Table 3.

Mention should also be made about the deal between ExxonMobil and Synthetic Genomics, where ExxonMobil invested US\$ 600 million in the synthetic biology firm for development of algae fuels using genetic engineering methodologies. This is not exactly a venture capital investment, but is more in the nature of a corporate investment [4].
TABLE 4: Algae companies funding.

\begin{tabular}{|c|c|c|}
\hline Company & Location & $\begin{array}{l}\text { Public/private } \\
\text { funding }\end{array}$ \\
\hline Aquaflow Bionomic & New Zealand & Public funding \\
\hline CEHMM & New Mexico, USA & Public funding \\
\hline Community Fuels & California, USA & Public funding \\
\hline General Atomics & California, USA & Public funding \\
\hline Kent Sea tech & Texas, USA & Public funding \\
\hline Patriot Biofuels & North Carolina, USA & Public funding \\
\hline Bodega Algae & Boston, USA & Public funding \\
\hline Green shift & Nebraska, USA & Public funding \\
\hline $\begin{array}{l}\text { Green Plains Renewable } \\
\text { Energy }\end{array}$ & New York, USA & Public funding \\
\hline Solix Biofuels Inc. & Colorado, USA & Public funding \\
\hline Algae Biosciences Corp. & Arizona, USA & Private funding \\
\hline AlgaTechnologies, Ltd. & Israel & Private funding \\
\hline Algenol Biofuels & Texas, USA & Private funding \\
\hline A2BE Carbon Capture & Colorado, USA & Private funding \\
\hline Bioverda & Dublin, Ireland & Private funding \\
\hline Blue Sun Biodiesel & Colorado, USA & Private funding \\
\hline Community Fuels & California, USA & Private funding \\
\hline LiveFuels & California, USA & Private funding \\
\hline Petro Algae & Florida, USA & Private funding \\
\hline Primafuel & California, USA & Private funding \\
\hline
\end{tabular}

Source: [4].

Unprecedented investment by private companies has spurred public investment to encourage the development of this technology. Cap and Trade schemes that are being implemented by a variety of states act to increase the cost of fossil fuels thereby promoting the development of other energy sources. Policy incentives aimed at increasing renewable energy will promote development. With the onset of new policy, incentives, massive investment in the private and public spheres, more researchers than ever are making forging new understanding in the science required to make algal biofuels economically feasible [18].

In order to boost the development of this technology, a few algae companies that have received funding directly from the government and a few others from government aided organizations are listed below. Other startups which received private funding are also listed in Table 4.

Most of the algae biofuel production so far was made in experimental facilities with low capacity of fuel production. With many companies expanding their facilities, it is expected that economies of scale result, now that production is increasing and average costs of cultivating algae are falling (and marginal costs are below average cost) [29].

With the production of many products in algae cultivation (as it was a refinery), technical efficiency can arise in the joint production of two or more products. If the cost of producing two products by one firm is less than the cost of producing the same two products by two firms, the production process exhibits economies of scope [29]. 
Therefore, it is expected a reduction in price of algae biofuels in the coming years.

In this context, it is also expected that the efficiency of such companies rises. It is possible to differentiate "technical efficiency" and "economical efficiency." Technical efficiency implies that the maximum output has been produced with a given set of inputs. Economical efficiency implies that the maximum output has been produced at a given (opportunity) cost or that a minimum (opportunity) cost has been achieved for a given level of output [29]. With a large set of alternatives of inputs and outputs within a developing market such as the algae one, it can be complex to achieve the technical and economical efficiency in the near future, but as the time goes by and the technology matures, better trends in production arise.

Hence, the main drawbacks of the microalgae technology to produce biofuels arise from economic nature: the price of this fuel [3] estimating the cost of producing a kilogram of microalgal biomass as US\$2.95 and US\$ 3.80 for photobioreactors and raceways, respectively. These estimates assume that carbon dioxide is available at no cost. If the annual biomass production capacity is increased to $10,000 \mathrm{t}$, the cost of production per kilogram reduces to roughly US\$ 0.47 and US\$ 0.60 for photobioreactors and raceways, respectively, because of economy of scale. Assuming that the biomass contains $30 \%$ oil by weight, the cost of biomass for providing a liter of oil would be something like US\$ 1.40 and US\$1.81 for photobioreactors and raceways, respectively [3].

In the United States during 2006, the on-highway petrodiesel price ranged between US\$ 0.66 and US\$ 0.79/L. This price included taxes (20\%), cost of crude oil (52\%), refining expenses (19\%), and distribution and marketing (9\%). If taxes and distribution are excluded, the average price of petrodiesel in 2006 was US\$ 0.49/L with a $73 \%$ contribution from crude oil and 27\% contribution from refining [3].

Therefore, algal biodiesel has to be cheap to compete as significant source of energy by 2030. According to [3], for algal biodiesel to potentially replace fossil fuels, it must be priced as follows: $C_{\text {algal oil (per liter) }} \leq 6.9 \times 10^{-3} \times$ $C_{\text {Petroleum (per barrel) }}$. For example, if crude oil is priced at US\$ 122/bbl (price on April 16th, 2011), algal biodiesel must be priced at less than US $\$ 0.84 / \mathrm{L}$ to offer a competitive alternative. Given the long-term uptrend in crude oil prices, the real competitive price level for algal biodiesel can be far higher and it could be nearer than predicted.

However, the costs of producing algae for biofuels vary a lot from study to study making it economically feasible or impossible to be competitive. The cost for producing one liter of oil can range from US $\$ 0.43$ to 24.60 depending on the study, making it difficult to forecast prices in the near future [30]. The economical feasibility of microalgae is one of the main drawbacks of this technology for producing biofuels as algal biofuel has to be cheap to compete as a technology for producing biofuels.

3.2. SWOT Analysis. With the purpose of clearing all the possibilities and threats of this technology, a SWOT (Strengths,
Weaknesses, Opportunities, and Threats) analysis is hereby developed. A SWOT analysis is a common tool used to plan and understand the four major categories involved in a project, business, or technology.

SWOT analysis has its origins from a research conducted at Stanford Research Institute from 1960-1970. The background to SWOT stemmed from the need to find out why corporate planning failed. By sorting the SWOT issues one can obtain a system which presents a practical way of assimilating the internal and external information about the business unit, delineating short- and long-term priorities, and allowing an easy way to build the management team which can achieve the objectives of profit growth [31].

For using such tool, it is needed to specify the objective of the project and identify the internal and external factors that are supportive or unfavourable to achieve that objective. SWOT is often used as part of a strategic planning process.

The objective here would be the massification and use of algal biofuels over the next 30 years. In Table 5, it is shown the strengths, weaknesses, opportunities, and threats of algal technology for biofuels.

\section{Conclusion}

The continued use of fossil fuels for energetic purposes is gradually becoming clearer to the society that is unsustainable. Innovative technologies and sources of energy must be developed to replace fossil fuels. However, alternative sources of biofuel derived from terrestrial crops such as sugarcane, soybeans, maize, rapeseed, among others inflict a lot of pressure on the global food markets, contribute to water scarcity and precipitate the destruction of forests. Besides that, many countries cannot grow most of the terrestrial crops due to climate factors or lack of fertile cultivation areas for energetic purposes. In this context, algal biofuels can really make a contribution for the future world sustainability.

Algae biofuel technological advances in cultivation and extraction of oil are scientifically well known and should continue to move forward in the coming years with increasing investment in $\mathrm{R} \& \mathrm{D}$ in this area. However, as shown in this paper, many are the challenges for this technology to be successful and produce biofuel in an economically viable manner in the coming years.

Biofuel production needs to be set in place and an efficient distribution system needs to be organized to bring biofuels to the market. For the establishment of a credible market, steady and with a growing demand, it needs to be stimulated as many of the implementation stages of emerging technologies can face limitations that can lower the possibility of success. In this way, with adequate policy support and incentives, the algal biofuel industry is prone to develop, and assuming that this technology follows renewable energy cost trends, costs will decrease to eventual economic viability.

Nevertheless, as shown in this paper, we are witnessing a rise of companies' strategies of entering new markets. For instance, during March and April 2011, news was published, both in Europe and the US, reporting new activities of 
TABLE 5: A SWOT analysis for microalgae.

Positive
Strengths
(i) Algal-oil processes into biodiesel as easy as oil derived from
land-based crops.
(ii) Algae are the fastest-growing plants in the world. The per
unit area yield of oil from algae is estimated to be $7-31$ times
greater than the next best crop, palm oil

Internal (iii) Algae consume carbon dioxide as they grow

(iv) Algae are very important as a biomass source

(v) Algae can be grown almost anywhere, even on sewage or salt water and do not require fertile land or food crops

\section{Opportunities}

(i) Possibility of production of other higher value products for commercialization [28] and access other markets

(ii) Subsidies and policies could turn this technology economically feasible

(iii) As algae consume carbon dioxide as they grow, they External could be used to capture $\mathrm{CO}_{2}$ from power stations and other industrial plants that would otherwise go into the atmosphere

(iv) Integrated algae-based biorefinery model could be adopted

(v) Algae-based fuel properties allow the use in jet fuels
Negative

Weaknesses

(i) Difficult to find an algal strain with a high lipid content and fast growth rate that is not too difficult to harvest, costeffective and that is best suited to region where it is going to be produced (genetic modified species could be a solution, but it causes another threat)

(ii) Not the same species for different regions

(iii) Still commercially immature technology: no many largescale companies in production

(iv) Environmental sustainability of algae-based biofuel is still uncertain due to insufficient data and not many Life Cycle Assessment (LCAs) have been made

(v) Extraction and processing is still expensive compared to other biofuels

(vi) Large-scale production could present many other drawbacks compared to those found in laboratory experiments

\section{Threats}

(i) If future demand for biofuels fall radically, this industry could face bankruptcy

(ii) Market and societal acceptance is still unclear

(iii) If genetically modified, it could generate regulatory limitations and societal disavowal

(iv) Diffusion difficulties: the large number of competing fuels could delay algal biofuels to achieve high growth on the basis of cost

Source: authors.

algae based companies $[32,33]$. These are signs that the uncertainties around the commercialization of this still not mature technology are not sufficient to hinder investment decisions.

\section{Acknowledgments}

This work has been partially supported by FCT under Project Grant PEst-C/EEI/UI0308/2011 and the Brazilian National Council for the Improvement of Higher Education (CAPES).

\section{References}

[1] European Commission (EC)—SETIS Strategy Energy Technologies Information System, "Bioenergy," http://setis.ec.europa.eu/technologies/Bioenergy/info, 2012.

[2] M. J. Groom, E. M. Gray, and P. A. Townsend, "Biofuels and biodiversity: principles for creating better policies for biofuel production," Conservation Biology, vol. 22, no. 3, pp. 602-609, 2008.

[3] Y. Chisti, "Biodiesel from microalgae," Biotechnology Advances, vol. 25, no. 3, pp. 294-306, 2007.

[4] Oligae, Oligae Report Academic Edition, http://www.oilgae.com/, 2010.
[5] L. Tao and A. Aden, "The economics of current and future biofuels," In Vitro Cellular and Developmental Biology, vol. 45, no. 3, pp. 199-217, 2009.

[6] L. Brennan and P. Owende, "Biofuels from microalgae-a review of technologies for production, processing, and extractions of biofuels and co-products," Renewable and Sustainable Energy Reviews, vol. 14, no. 2, pp. 557-577, 2010.

[7] A. P. Carvalho, L. A. Meireles, and F. X. Malcata, "Microalgal reactors: a review of enclosed system designs and performances," Biotechnology Progress, vol. 22, no. 6, pp. 1490-1506, 2006.

[8] A. Hirano, R. Ueda, S. Hirayama, and Y. Ogushi, " $\mathrm{CO}_{2}$ fixation and ethanol production with microalgal photosynthesis and intracellular anaerobic fermentation," Energy, vol. 22, no. 2-3, pp. 137-142, 1997.

[9] E. Ono and J. L. Cuello, "Feasibility assessment of microalgal carbon dioxide sequestration technology with photobioreactor and solar collector," Biosystems Engineering, vol. 95, no. 4, pp. 597-606, 2006.

[10] O. Pulz, "Photobioreactors: production systems for phototrophic microorganisms," Applied Microbiology and Biotechnology, vol. 57, no. 3, pp. 287-293, 2001.

[11] O. Pulz and W. Gross, "Valuable products from biotechnology of microalgae," Applied Microbiology and Biotechnology, vol. 65, no. 6, pp. 635-648, 2004. 
[12] J. Sheehan, T. Dunahay, J. Benemann, and P. Roessler, A Look Back at the U.S. Department of Energy's Aquatic Species Program-Biodiesel from Algae, National Renewable Energy Laboratory, Golden, Colo, USA, 1998.

[13] P. Spolaore, C. Joannis-Cassan, E. Duran, and A. Isambert, "Commercial applications of microalgae," Journal of Bioscience and Bioengineering, vol. 101, no. 2, pp. 87-96, 2006.

[14] K. L. Terry and L. P. Raymond, "System design for the autotrophic production of microalgae," Enzyme and Microbial Technology, vol. 7, no. 10, pp. 474-487, 1985.

[15] C. U. Ugwu, H. Aoyagi, and H. Uchiyama, "Photobioreactors for mass cultivation of algae," Bioresource Technology, vol. 99, no. 10, pp. 4021-4028, 2008.

[16] L. M. Brown, "Uptake of carbon dioxide from flue gas by microalgae," Energy Conversion and Management, vol. 37, no. 68, pp. 1363-1367, 1996.

[17] K. B. Cantrell, T. Ducey, K. S. Ro, and P. G. Hunt, "Livestock waste-to-bioenergy generation opportunities," Bioresource Technology, vol. 99, no. 17, pp. 7941-7953, 2008.

[18] UNESCO, "The ethics of adoption and development of algae-based biofuels," UNESCO 83, McGraw-Hill, Bangkok, Thailand, 2009.

[19] P. T. Pienkos and A. Darzins, "The promise and challenges of microalgal-derived biofuels," Biofuels, Bioproducts and Biorefining, vol. 3, no. 4, pp. 431-440, 2009.

[20] T. Searchinger, R. Heimlich, R. A. Houghton et al., "Use of U.S. croplands for biofuels increases greenhouse gases through emissions from land-use change," Science, vol. 319, no. 5867, pp. 1238-1240, 2008.

[21] L. Rodolfi, G. C. Zittelli, N. Bassi et al., "Microalgae for oil: strain selection, induction of lipid synthesis and outdoor mass cultivation in a low-cost photobioreactor," Biotechnology and Bioengineering, vol. 102, no. 1, pp. 100-112, 2009.

[22] J. Qin, Bio-Hydrocarbons from Algae-Impacts of Temperature, Light and Salinity on Algae Growth, Rural Industries Research and Development, Barton, Australia, 2005.

[23] M. L. Ghirardi, L. Zhang, J. W. Lee et al., "Microalgae: a green source of renewable $\mathrm{H}_{2}$," Trends in Biotechnology, vol. 18, no. 12, pp. 506-511, 2000.

[24] O. Pulz and K. Scheinbenbogan, "Photobioreactors: design and performance with respect to light energy input," Advances in Biochemical Engineering/Biotechnology, vol. 59, pp. 123-152, 1998.

[25] P. Chen, M. Min, Y. Chen et al., "Review of the biological and engineering aspects of algae to fuels approach," International Journal of Agricultural and Biological Engineering, vol. 2, no. 4, pp. 1-30, 2009.

[26] J. R. Benemann, "Microalgal biofuels: a brief introduction," 2009, http://advancedbiofuelsusa.info/wp-content/uploads/ 2009/03/microalgae-biofuels-an-introduction-july23-2009benemann.pdf.

[27] A. L. Ahmad, N. H. M. Yasin, C. J. C. Derek, and J. K. Lim, "Microalgae as a sustainable energy source for biodiesel production?: a review," Renewable and Sustainable Energy Reviews, vol. 15, no. 1, pp. 584-593, 2011.

[28] J. Singh and S. Gu, "Commercialization potential of microalgae for biofuels production," Renewable and Sustainable Energy Reviews, vol. 14, no. 9, pp. 2596-2610, 2010.

[29] G. Rothwell, Electricity Economics: Regulation and Deregulation, IEEE Press, New Jersey, NJ, USA, 2000.

[30] L. A. Ribeiro and P. P. Silva, "Policies and challenges for advanced biofuel technologies: a look into microalgae," in Proceedings of the 6th Dubrovnik Conference on Sustainable
Development of Energy, Water and Environment Systems (SDEWES '11), pp. 25-29, Dubrovnik, Croatia, September 2011.

[31] A. S. Humphrey, "History of the SWOT analysis," http:// rapidbi.wordpress.com/2008/12/29/history-of-the-swot-analysis/, 2004.

[32] M. Rosenthal, "Leveling the playing field for algae-based fuels," March 2011, Biofuels Digest, http://www.biofuelsdigest .com/bdigest/2011/03/31/leveling-the-playing-field-for-algaebased-fuels/.

[33] BFS, "The world's first ecological oil is made using profitable industrial process?” BFS Blue Petroleum, http://www.biopetroleo.com/english/noticia/the-worlds-first-ecological-oil-ismade-using-profitable-industrial-processes/,, 2011. 

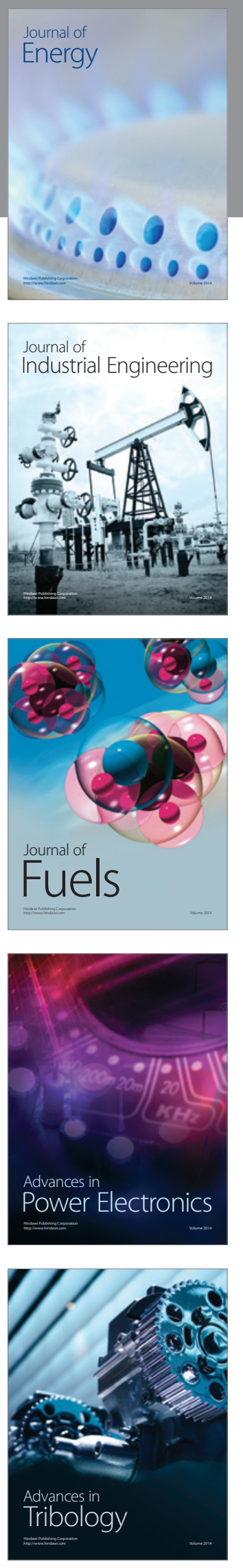
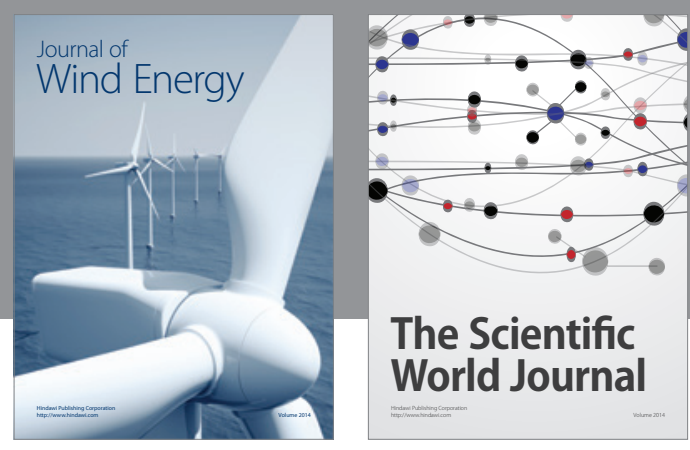

The Scientific World Journal

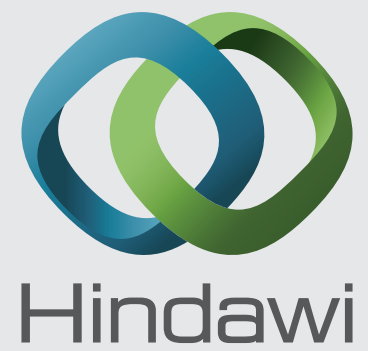

Submit your manuscripts at http://www.hindawi.com
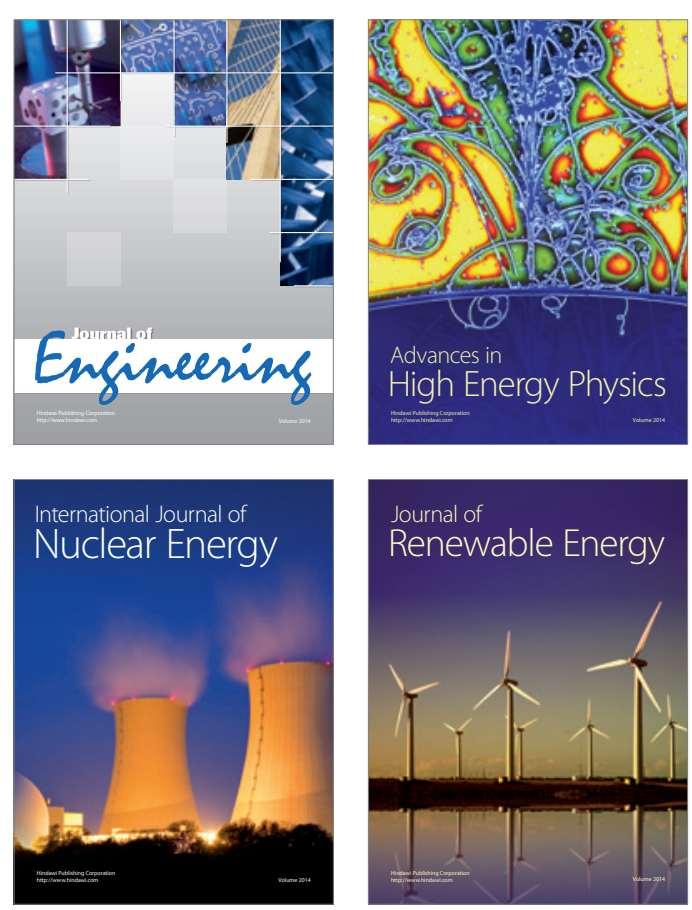

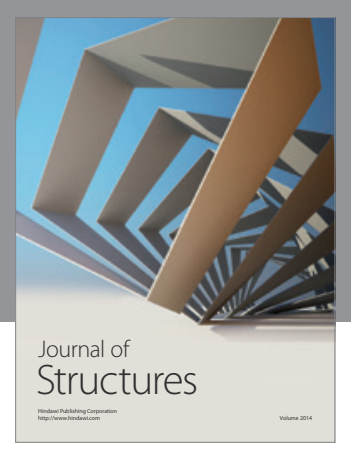

Rotating
Mechinery
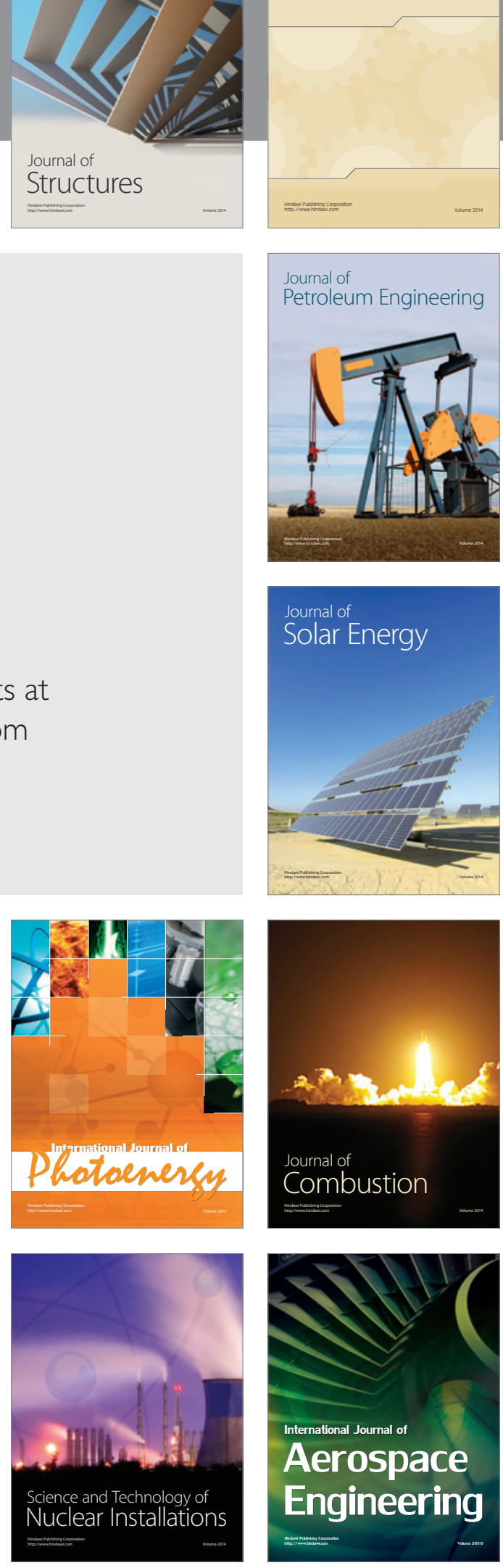